\title{
Habitat selection and adult-larvae interactions in settling larvae of soft-shell clam Mya arenaria
}

\author{
P. V. R. Snelgrove ${ }^{1, *}$, J. Grant ${ }^{2}$, C. A. Pilditch ${ }^{3}$ \\ ${ }^{1}$ Fisheries Conservation Chair, Fisheries and Marine Institute, Memorial University of Newfoundland, \\ St. John's, Newfoundland A1C 5R3, Canada \\ ${ }^{2}$ Department of Oceanography, Dalhousie University, Halifax, Nova Scotia B3H 4J1, Canada \\ ${ }^{3}$ Department of Biological Sciences, University of Waikato, Hamilton, Private Bag 3105, New Zealand
}

\begin{abstract}
Like many benthic taxa, the soft-shell clam Mya arenaria L. is patchily distributed in nature. Near Halifax, Canada (Eastern Passage), $M$. arenaria and several other species (Polydora cornuta, Pygospio elegans, Gemma gemma, Hydrobia sp.) occur in higher densities at a sheltered site than at an exposed site $\sim 300 \mathrm{~m}$ away with similar grain size but different sediment organic texture. Total faunal densities at the exposed site were comparatively low. To evaluate whether larval settlement plays a role in establishing $M$. arenaria patterns, laboratory flume experiments were conducted with competent $M$. arenaria larvae. Natural cores from the sheltered and exposed sites with resident infauna intact, as well as cores from the same sites that had been defaunated by freezing, were inserted flush with the flume bottom. Highest settlement was observed in faunated cores from the sheltered site where $M$. arenaria are more common. Significantly lower settlement was observed in other treatments, including defaunated cores from the sheltered site. For corresponding treatments, settlement in sediment from the exposed site was less than that at the sheltered site. Of the abundant taxa in intact flume cores, Gemma gemma densities were a significant, albeit weak predictor of $M$. arenaria settlement. We propose that G. gemma influence interface sediment characteristics which, in turn, result in differential larval response. Settlement patterns contradict a previous study (Emerson \& Grant 1991; Limnol Oceanogr 36:1288-1300) that reported an absence of recently settled $M$. arenaria spat at the sheltered site, despite high numbers at the nearby exposed site. The contrast in results likely reflects our focus on settlement and their focus on spat abundance, and these results considered in tandem suggest that both pre- and post-settlement processes likely determine soft-shell clam distributions at Eastern Passage.
\end{abstract}

KEY WORDS: Mya arenaria - Clam - Intertidal - Settlement - Flume L Larvae Polydora cornuta . Gemma gemma. Pygospio elegans

\section{INTRODUCTION}

One of the most basic problems in benthic ecology is in understanding why variability in spatial and temporal patterns exists in soft-sediment communities (Butman 1987, Ólafsson et al. 1994, Snelgrove \& Butman 1994). One explanation for this variability is that active choice for a specific sedimentary environment, in the form of habitat selection by settling larvae, may increase the likelihood of placing offspring into that

\footnotetext{
-E-mail: psnelgro@gill ifmt.nf.ca
}

habitat, although differences in larval supply through passive transport (Butman 1987) as well as post-settlement processes (Wilson 1991) offer equally viable hypotheses.

Field studies lend credence to the importance of larval supply (Muus 1973. Cameron \& Rumrill 1982, Günther 1991, 1992) and small-scale flow effects (Eckman 1983, Luckenbach 1986, Snelgrove 1994) in establishing pattern in different environments, but there is also considerable experimental field data suggesting that larval interactions with resident macro- (Woodin 1976,1985, Ambrose 1984, Tamaki 1985, Turner et al. 1997) and meiofauna (Bell \& Coull 1980, Watzin 1986) 
may also be important. Post-settlement predation has also been demonstrated to be a major structuring force in soft-sediment environments (Peterson 1979, 1982).

Flume experiments suggest that species with some degree of habitat specificity as adults have larvae that preferentially settle in defaunated sediments typical of their adult environment (Butman et al. 1988, Butman \& Grassle 1992, Grassle et al. 1992a,b, Snelgrove et al. 1993, 1998). These experiments have deliberately utilised defaunated sediments to test how specific variables such as organic content (e.g. Butman et al. 1988, Butman \& Grassle 1992, Grassle et al. 1992a,b), nearbed flow (Jonsson et al. 1991, Snelgrove et al. 1993), individual species interactions (André et al. 1993), and species-specific compounds (e.g. Woodin et al. 1993) may impact initial larval settlement. Thus, a logical progression in the use of laboratory flumes in understanding marine benthos is to use natural communities in experimental manipulations. Field approaches to this question are often complicated by complex and difficult to control variables such as storms (Emerson \& Grant 1991), transient predators (Hall et al. 1991), and variability in larval supply (Luckenbach 1984). Laboratory flume experiments allow reproduction of representative bottom flow but under the controlled conditions of a laboratory setting. Near-bottom flow is relevant to many benthic processes (Nowell \& Jumars 1984), including larval settlement.

The soft-shell clam Mya arenaria L. is broadly distributed throughout shallow northern boreal waters. Populations tend to be highest in muddy sand areas (Gosner 1978, Günther 1992) and can often be patchy on multiple scales. One such example is Eastern Passage, Nova Scotia, Canada, where population dynamics of $M$. arenaria differ markedly between a sheltered and an exposed intertidal site located only hundreds of meters apart. Prior work indicates that despite the differences in wave exposure, the bulk grain size $(\sim 250 \mu \mathrm{m})$ and silt-clay content $(\sim 0.5 \%)$ of sediments are similar and several species occur at both sites (Emerson \& Grant 1991). Nonetheless, the sites differ in several respects. Faunal densities at the exposed site are comparatively low, and the most abundant species at the sites, including $M$. arenaria, occur in higher densities at the sheltered site. Gemma gemma, Hydrobia sp., and Arenicola marina occur only at the sheltered site and Spisula sp. occurs only at the exposed site (Emerson \& Grant 1991). In addition, an organic mineral aggregate fluff layer is observed only at the sheltered site, along with a reduced carbon:nitrogen ratio suggestive of more abundant microalgae (Grant \& Emerson 1994). M. arenaria spat densities and transport have also been found to be substantially higher at the exposed site during some times of the year (Emerson \& Grant 1991).
The goal of the present study is to use laboratory flume simulations to determine how differences in sediment composition and natural infaunal communities may influence habitat selection by settling $M y a$ arenaria larvae and thus contribute to $M$. arenaria population dynamics.

\section{MATERIALS AND METHODS}

Eastern Passage fauna and flume sediment treatments. Eastern Passage is located in outer Halifax Harbour, Nova Scotia (Fig. 1), and the Sheltered Site and Exposed Site that are the focus of this study are located approximately $300 \mathrm{~m}$ apart. In order to compare faunas at the 2 sites, $6.5 \mathrm{~cm}$ diameter cores were pushed to $10 \mathrm{~cm}$ depth during collections on July 19, 1996 (4 replicates site ${ }^{-1}$ ). The choice of core size represented a compromise between being sufficiently small to allow enumeration of the most abundant taxa, and being sufficiently large to sample bigger organisms. Undoubtedly, larger individuals of Mya arenaria, Arenicola marina and Spisula sp. were not effectively enumerated by this sampling. Spot checks of cores collected on August 4 and August 12, 1996, when the second and third sets of flume experiments were conducted, indicated no obvious changes in faunal composition and no large pulses of $M$. arenaria settlement in the field during that time which might have confounded interpretation of settlement patterns in the flume. Cores were preserved in $10 \%$ buffered formalin and transferred to $80 \%$ ethanol within $2 \mathrm{wk}$ of sampling. Samples were processed over a $106 \mu \mathrm{m}$ sieve to ensure that recently settled macrofauna would also be effectively enumerated. In most cases, fauna could be identified to species.

Sediments used in the flume experiments were collected from the Sheltered and Exposed Sites, and included cores that were either left intact (hereafter referred to as 'Infauna' cores) or defaunated by freezing (hereafter referred to as 'No Fauna' cores). For No Fauna cores, bulk sediments were collected from both sites in July, 1996, at low tide by scraping the upper 2 to $3 \mathrm{~cm}$ of sediments into large plastic storage containers, rinsing several times with fresh water and allowing fine particles to settle before decanting. Large shell fragments and dead organisms were removed. Sediments were frozen until the day prior to experiments and sediment from the same collection was used in all flume experiments. On the day of an experiment, No Fauna sediments were stirred vigorously and the sediments allowed to settle before coring with $4.36 \mathrm{~cm}$ diameter cores.

Preparation of Infauna cores was delayed until an experiment was imminent. For a given set of experi- 


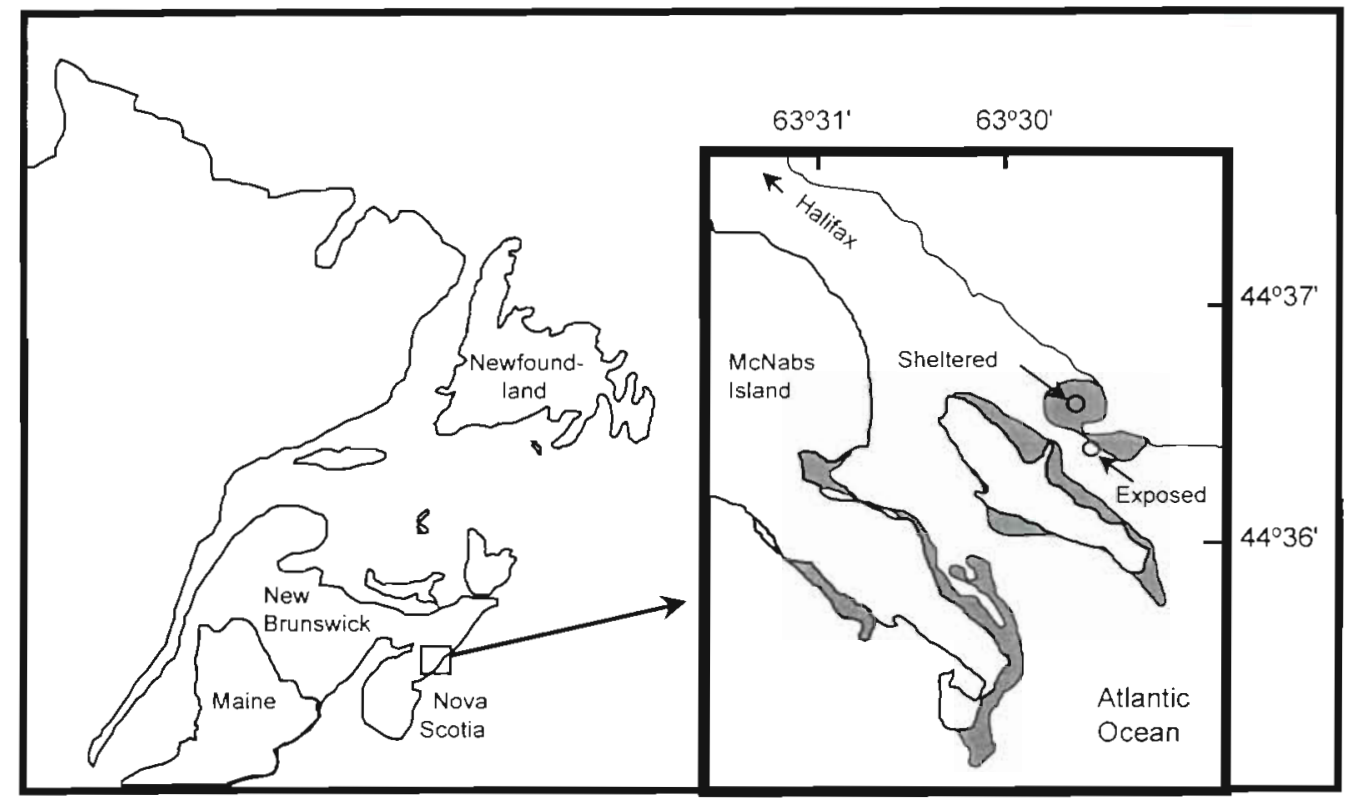

Fig. 1 Location of study sites within Halifax Harbour, Nova Scotia, Canada. Grey areas indicate intertidal areas and circles denote sampling sites. Eastern Passage is the channel in which both sampling sites are located ments, six $11.4 \mathrm{~cm}$ diameter infaunal cores were collected from the Exposed and Sheltered Sites at Eastern Passage and transported to Dalhousie, Halifax, Nova Scotia, in coolers with ice packs. At Dalhousie's aquatron facility, cores were maintained in filtered, running seawater until used in experiments within the next $72 \mathrm{~h}$. Infauna cores from each of the 2 sites were subsampled immediately prior to a flume run by pushing a $4.36 \mathrm{~cm}$ diameter core into the larger core and pulling away the larger core making sure that seawater was maintained above the sediment and that the sediment surface was well below the top of the smaller core. An $O$-ring sealed plug was then inserted in the bottom of the core to prevent sediment loss. The purpose of the smaller cores was 2 -fold. First, edge effects associated with the outer periphery of the larger cores would be eliminated: We reasoned that the periphery of cores would have the most anomalous biology and geochemistry and that these effects would be exacerbated during storage of cores between flume runs; recoring would introduce a new edge effect but of lesser magnitude. The smaller cores also allowed cross-stream placement of 4 cores with minimal flume wall effects (see below); larger cores would have necessitated fewer treatments. All sediments and cores were collected between mid-July and mid-August, and were therefore chosen to correspond approximately to annual peak Mya arenaria settlement at Eastern Passage as documented by Emerson \& Grant (1991).

Conditioning adults. Eastern Passage, though not obviously polluted, is sufficiently close to Halifax Harbour that a more pristine site was felt to be more suitable for obtaining adults for conditioning, and in April,
1996, -60 adult Mya arenaria (individuals 5 to $7 \mathrm{~cm}$ in length) were collected from Lawrencetown Beach, a site $-12 \mathrm{~km}$ northeast of Eastern Passage.

Adults were maintained in running seawater at approximately $17^{\circ} \mathrm{C}$. During a $2 \mathrm{~h}$ period each day flow was shut of and concentrated algae from Coast Oyster Company and from live laboratory cultures (Isochrysis sp., Thalassiosira pseudonana and/or Chaetoceros muelleri) were downwelled through the sediments where adults were maintained (initial concentration of 100000 cells ml-1 in 1000 l). Adults were conditioned for -3 mo and spawned by placing at least 15 individuals overnight in filtered, aerated seawater warmed to $-22^{\circ} \mathrm{C}$. The following morning, larvae were collected on a $20 \mu \mathrm{m}$ sieve, distributed into $20 \mathrm{l}$ containers and maintained at concentrations of less than 10 ind. $\mathrm{ml}^{-1}$. Larvae were fed a mixture of Isochrysis $\mathrm{sp}$ and $T$. pseudonana at a combined concentration of $\sim 50000$ cells $\mathrm{ml}^{-1}$, and seawater was changed every second day during the 10 to $13 \mathrm{~d}$ it took between fertilization and a given experiment.

Competency. Timing of experiments was reliant on a batch (i.e. individuals from a single spawning) of cultured larvae being physiologically competent to settle. The primary criterion for evaluating larval competency was observation of several hundred individuals from cultures to see whether pediveligers were present. Once $-5 \%$ of individuals appeared to have attained a pediveliger stage, a series of flume experiments was initiated within the next $12 \mathrm{~h}$. In addition, once pediveligers were present, still-water competency tests were conducted concurrently with flume experiments. Competency tests were similar to those described else- 
where for bivalves (e.g. Grassle et al. 1992a, Snelgrove et al. 1993, 1998) and are not reported here except to note that they supported the assumption that at least some of the larvae in a given batch were competent during all experiments.

The flume. All flume experiments were conducted in the recirculating flume at Dalhousie described in Roegner et al. (1995). Briefly, the flume consists of a $7.32 \mathrm{~m}$ long, $50 \mathrm{~cm}$ wide, and $50 \mathrm{~cm}$ deep raceway with a $37 \mathrm{~cm}$ diameter return pipe that runs beneath the flume and an impeller that regulates flow speed via a variable speed DC motor. In the test section of the flume $(529 \mathrm{~cm}$ downstream of the entrance) 4 holes were cut in the flume floor to allow insertion of cores (inner diameter $=4.36 \mathrm{~cm}$ ) containing the sediment treatments. Cores were distributed across the flume, perpendicular to the raceway, and confined to the central $25 \mathrm{~cm}$ in the cross-stream direction. This placement reduced the likelihood of wall effects associated with treatments located too close to the flume walls (see Nowell \& Jumars 1987). Cores were inserted flush with the flume floor and held in place with nylon collars fitted with internal $\mathrm{O}$-rings secured to the underside of the flume that created a watertight seal.

Experimental protocol. After cores with live infauna had been collected in the field, the return pipe in the flume was filled with seawater pumped in from a comparatively clean area of Halifax. Harbour and filtered to $5 \mu \mathrm{m}$. Water was added to the pipe until no more water could be added without flooding the flume raceway. Each core containing 1 of the 4 treatments was inserted from the underside of the flume until the rim of the plastic core barrel was flush with the flume bottom. Additional filtered seawater was then added to the flume until the water depth in the runway was $10 \mathrm{~cm}$. Sediment in the cores was raised until flush with the flume bottom using a modified turnbuckle to push up the O-ring fitted plastic plug and the sediment above it. Flow was then turned on to achieve a $u$. of $\sim 0.7 \mathrm{~cm} \mathrm{~s}^{-1}$, as calculated earlier from velocity profiles collected with a hot wire anemometer (DanTech) using the log-profile technique (e.g. Jumars \& Nowell 1984). Flow was characterized separately from runs with larvae present to avoid any interaction between the hot wire probe and larvae; flows were reproduced for runs with larvae by duplicating water depth and pump speed. This shear velocity is within the typical range observed at Eastern Passage (Emerson \& Grant 1991), and although higher shear velocities do occur (particularly in the fall), we deliberately chose a flow regime below the critical shear velocity of the sediment $\left(\sim 1.0 \mathrm{~cm} \mathrm{~s}^{-1}\right.$, Emerson \& Grant 1991). In addition to the complication that would arise if sediments were eroding during experiments, the semi-diurnal tides over the sandflats are insufficient in themselves to move sediments and require wind input greater than is typical for the site in July and August (Emerson 1991). The impeller rotation rate required to achieve this flow speed was surprisingly slow, so that damage to swimming larvae was expected to be negligible. Approximately 40000 larvae were added at the upstream end of the flume by pouring them from a beaker that was moved slowly back and forth in the cross-stream direction. The windowless room was lit by fluorescent bulbs well above the flume; during flume experiments lights were kept on at all times, whereas during culturing they were maintained on a $12 \mathrm{~h}$ light-dark cycle.

Each experimental run lasted $12 \mathrm{~h}$, after which a $100 \mu \mathrm{m}$ mesh net that fit tightly across the full width and depth of the flume was placed in the flume for 5 min to filter out any remaining suspended larvae. Once filtering was completed, the flow was turned off, weighted caps were placed over the sediment cores, and the flume was drained down and sponged until the raceway was dry. Sediments were then carefully removed from the top $2 \mathrm{~cm}$ of each core and preserved in $10 \%$ buffered formalin; within 2 wk samples were transferred to $80 \%$ ethanol and Rose Bengal for later enumeration of settled Mya arenaria and all macrofauna. Core barrels were then removed from the flume, rinsed, and fresh cores were prepared and inserted into the flume as described above, except that cross-stream positions were shifted. A. new aliquot of 40000 larvae from the same larval batch was then added and a second experimental run initiated. This procedure was repeated 2 more times so that each treatment occupied a different position in each of the 4 successive runs for a given larval batch in a Latin squares design. The same protocol was repeated with 3 different batches of larvae for a total of 12 experimental runs ( 3 batches $\times 4$ runs batch ${ }^{-1}$ ).

Data analysis. Flume settlement data were analyzed in a single mixed model nested analysis of variance (ANOVA) in which $y=$ constant + Batch + Column + Treatment + Run (Batch) + Treatment $\times$ Batch + Column $\times$ Batch + error; $y$ refers to number of settled Mya arenaria larvae, Batch refers to larval batch, Column refers to cross-stream position in the flume, Treatment refers to the sediment treatments described above, and Run refers to sequential experiments conducted with larvae of the same batch. $M$. arenaria densities were $\log (x+1)$ transformed to homogenize variances. Not all interaction terms could be tested in a single analysis because of insufficient degrees of freedom, and only those considered to be most important were included.

In order to determine whether resident infauna impacted larval settlement, linear regression analysis was performed separately for the 7 taxa that were abundant in Sheltered Infauna cores. Multiple regres- 
sion was not used because of problems with co-linearity of different taxa. Thus, the general model was $y=m$ (infaunal density) + constant, where $y$ refers to number of settled Mya arenaria larvae, $m$ refers to slope, constant refers to the $y$ intercept and infaunal density refers to densities of Gemma gemma, Hydrobia sp., Pygospio elegans, Polydora cornuta, Oligochaeta spp., or adult $M$. arenaria in Sheltered Faunated cores. Other core treatments were not pooled for regression analysis because of the significant Treatment effect observed in the analysis described above (see 'Discussion'), and the complete absence of infauna in No Fauna cores. Densities of infauna in Exposed Infauna cores were so low that regression analysis for this treatment would not have been meaningful.

\section{RESULTS}

Cores collected from the Sheltered and Exposed Sites revealed that, although bulk sediment characteristics are similar, the sediment structure at the sediment surface was quite different (Grant \& Emerson 1994). The Sheltered Site had a fluffy looking sediment that clearly had very fine material concentrated at the sediment-water interface and many aggregates attached to grains. At the Exposed Site, a fluffy grain layer was not apparent, and there was little evidence of biological activity. In addition to differences in flow regime, faunal cores indicated substantial faunal differences between the 2 sites that may contribute to the observed differences in biological structure. The polychaetes Polydora cornuta, Pygospio elegans, and Capitella spp., Oligochaeta spp., and the molluscs Gemma gemma, Hydrobia sp., and Mya arenaria were all more abundant at the Sheltered Site; total faunal densities at the Exposed Site were very low in comparison with those at the Sheltered Site (Fig. 2). All of the dominant taxa at the Exposed Site were also present at the Sheltered Site but in very low abundance. In addition to adults, a few small individuals of $M$. arenaria were noted in some cores, but all were sufficiently large that they could not have been confused with $M$. arenaria larvae that settled during flume experiments.

Competency tests for Mya arenaria larvae produced less than definitive results in terms of proportion of competent larvae and selectivity. However, at least a few individuals settled and metamorphosed during each of the competency tests, indicating that some portion of the culture was competent to settle during all. experimental runs.
Conditions for all flume experiments are summarized in Table 1. Temperature was maintained within a fairly narrow range of 16.2 to $19.8^{\circ} \mathrm{C}$. Larval age for flume experiments ranged from 11 to $13 \mathrm{~d}$, depending on specific Run and Batch. Core age varied from 2 to $62 \mathrm{~h}$. Neither larval age nor core age had any consistent effect on patterns of settlement, in that Sheltered Infauna cores had highest settlement in all 12 experiments. Responses to other treatments appeared to vary more with different batches than with core age or larval age. Estimated recoveries in experimental runs ranged from 2.2 to $22.5 \%$ of the -40000 larvae added

ANOVA of flume settlement experiments indicated a significant Treatment effect as well as a significant Run (nested in Batch) effect (Table 2) with the general result that sheltered cores had higher settlement. A Tukey's multiple comparisons test indicated that significantly higher settlement occurred in Sheltered Infauna cores compared to all other treatments and that Sheltered No Fauna cores had significantly higher settlement than Exposed No Fauna cores. No other significant differences were observed. The significant Run effect can be attributed to changes in total settlement that occurred over different runs of a given Batch (Fig. 3). In the first set of flume experiments, total settlement increased as larvae became older. In the second and third experiments, settlement peaked during the second run (Table 1). Thus, there is no consistent trend regarding core or larval age and peak settlement.

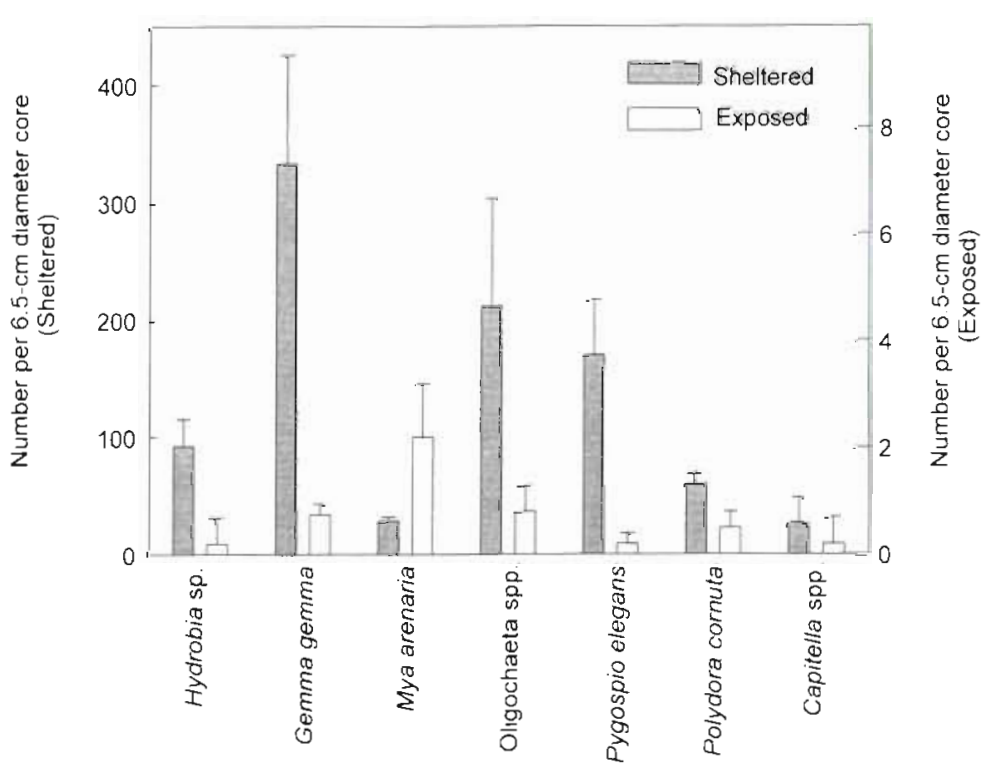

Fig. 2. Dominant macrofauna at Eastern Passage study sites. Bars denote means and lines denote $1 \mathrm{SE}(\mathrm{n}=4)$. Note that different axes are used for the 2 sites 
Table 1. Experimental conditions during each of the flume runs

\begin{tabular}{|c|c|c|c|c|c|c|c|c|c|}
\hline \multirow[t]{2}{*}{ Batch } & \multirow[t]{2}{*}{ Expt run } & \multirow[t]{2}{*}{ Start date } & \multirow{2}{*}{$\begin{array}{l}\text { Duration } \\
\text { (h) }\end{array}$} & \multirow{2}{*}{$\begin{array}{l}\text { Larval age } \\
\text { (d) }\end{array}$} & \multirow{2}{*}{$\begin{array}{c}\text { Core age } \\
\text { (h) }\end{array}$} & \multicolumn{2}{|c|}{ Water temp $\left({ }^{\circ} \mathrm{C}\right)$} & \multirow{2}{*}{$\begin{array}{c}\text { Approx. } \\
\text { number of } \\
\text { larvae added }\end{array}$} & \multirow{2}{*}{$\begin{array}{l}\text { Percent } \\
\text { larvae } \\
\text { recovered }\end{array}$} \\
\hline & & & & & & Start & Finish & & \\
\hline \multirow[t]{4}{*}{1} & A & 20 Jul 1996 & 12 & 11 & 18 & 16.2 & 17.4 & 40000 & 2.8 \\
\hline & $\mathrm{B}$ & 23 Jul 1996 & 12 & 12 & 34 & 16.8 & 17.6 & 40000 & 11.7 \\
\hline & $\mathrm{C}$ & 23 Jul 1996 & 12 & 12.5 & 48 & 17.0 & 18.0 & 40000 & 12.4 \\
\hline & $D$ & 24 Jul 1996 & 12 & 13 & 62 & 17.6 & 18.1 & 40000 & 13.1 \\
\hline \multirow[t]{4}{*}{2} & $A$ & 05 Aug 1996 & 12 & 11 & 12 & 17.9 & 19.2 & 40000 & 2.2 \\
\hline & B & 06 Aug 1996 & 12 & 11.5 & 26 & 18.6 & 19.4 & 40000 & 18.7 \\
\hline & $\mathrm{C}$ & 06 Aug 1996 & 12 & 12 & 40 & 18.9 & 19.8 & 40000 & 12.2 \\
\hline & $\mathrm{D}$ & 07 Aug 1996 & 12 & 12.5 & 56 & 19.0 & 19.8 & 40000 & 15.8 \\
\hline \multirow[t]{4}{*}{3} & A & 12 Aug 1996 & 12 & 10.5 & 2 & 18.2 & 19.0 & 40000 & 8.3 \\
\hline & $\mathrm{B}$ & 13 Aug 1996 & 12 & 11 & 17 & 18.6 & 19.3 & 40000 & 22.5 \\
\hline & $\mathrm{C}$ & 14 Aug 1996 & 12 & 11.5 & 30 & 18.7 & 19.5 & 40000 & 15.5 \\
\hline & $\mathrm{D}$ & 14 Aug 1996 & 12 & 12.5 & 48 & 18.9 & 19.5 & 40000 & 9.3 \\
\hline
\end{tabular}

Table 2. (a) ANOVA results with all batches included. Data were $\log (x+1)$ transformed to homogenize variances. Significant results are shown in bold. (b) Means were compared with a Tukey's multiple comparisons test. Lines connect means that were not significantly different

\begin{tabular}{|c|c|c|c|c|c|}
\hline \multicolumn{6}{|l|}{ (a) ANOVA } \\
\hline Treatment & & 3 & 63.120 & 30.100 & 0.001 \\
\hline Column & & 3 & 0.946 & 1.651 & 0.275 \\
\hline Batch & & 2 & 0.255 & 0.412 & 0.668 \\
\hline Treatment & Batch & 6 & 4.196 & 2.259 & 0.084 \\
\hline Column $\times \mathrm{B}$ & atch & 6 & 1.145 & 0.617 & 0.715 \\
\hline Run(Batch) & & 9 & 21.642 & 7.766 & 0.001 \\
\hline Error & & 18 & 5.573 & & \\
\hline \multicolumn{6}{|c|}{ (b) Tukey's multiple comparisons test } \\
\hline Treatment & \multicolumn{2}{|c|}{$\begin{array}{l}\text { Sheltered } \\
\text { Infauna }\end{array}$} & $\begin{array}{l}\text { Sheltered } \\
\text { No Fauna }\end{array}$ & \multicolumn{2}{|c|}{$\begin{array}{l}\text { Exposed Exposed } \\
\text { Infauna No Fauna }\end{array}$} \\
\hline Mean & 3577. & & 653.2 & 396.6 & 182.9 \\
\hline
\end{tabular}

Table 3. Regression analyses of dominant taxa from Sheltered Infauna cores as predictors of Mya arenaria settlement. Because a significant relationship was observed only for Gemma gemma, slopes and intercepts are not reported for other taxa. The regression equation for G. gemma is given in Fig. 4

\begin{tabular}{|lcccccc|}
\hline Taxon & $\mathrm{n}$ & SS regression & SS residual & $F$ & $\mathrm{p}$ & $\mathrm{r}^{2}$ \\
\hline Polydora cornuta & 12 & 2082039.66 & $4.68272 \times 10^{7}$ & 0.45 & 0.52 & 0.00 \\
Pygospio elegans & 12 & 199709.64 & $4.87095 \times 10^{7}$ & 0.04 & 0.84 & 0.00 \\
Oligochaeta spp. & 12 & 6296138.69 & $4.26131 \times 10^{7}$ & 1.48 & 0.25 & 0.04 \\
Capitella spp. & 12 & 1339.827 & $4.89079 \times 10^{7}$ & 0.00 & 0.99 & 0.00 \\
Hydrobia sp. & 12 & $1.10609 \times 10^{7}$ & $3.78483 \times 10^{7}$ & 2.92 & 0.12 & 0.15 \\
Gemma gemma & 12 & $1.87427 \times 10^{7}$ & $3.01665 \times 10^{7}$ & 6.21 & 0.03 & 0.32 \\
Mya arenaria & 12 & 9158003.51 & $3.97513 \times 10^{7}$ & 2.30 & 0.16 & 0.11 \\
\hline
\end{tabular}

Regression analyses indicated that, of the dominant macrofauna present in the Sheltered Infauna cores, only Gemma gemma was a significant predictor of Mya arenaria settlement (Table 3). G. gemma densities in Sheltered Infauna cores explained a significant amount of variation in $M$. arenaria settlement $\left(\mathrm{r}^{2}=\right.$ 0.32 ), and higher G. gemma densities were associated with higher $M$. arenaria settlement. Densities of Pygospio elegans, Polydora cornuta, Oligochaeta spp., adult M. arenaria, and Hydrobia sp. were not significant predictors of $M$. arenaria larval settlement.

\section{DISCUSSION}

The establishment of pattern in soft-sediment communities and the role that larval settlement plays is a largely unresolved debate in benthic ecology (e.g. Ólafsson et al. 1994, Snelgrove \& Butman 1994). Although there are important variables that can only be tested in situ, field experiments in which conditions are relatively 'natural' suffer from problems of appropriate time scales and stochastic processes that may or may not be known (see Gallagher et al. 1983). Laboratory experiments mimic nature poorly, and there is strong evidence that processes as varied as feeding (Miller et al. 1992), nutrient flux (Huettel \& Gust 1992) and larval settlement behaviour (Grassle et al. 1992a, Snelgrove et al. 1998) may change considerably in different flow regimes. As such, laboratory flumes that reproduce representative flow regimes have been instrumental in demonstrating selective capacity of settling larvae. 

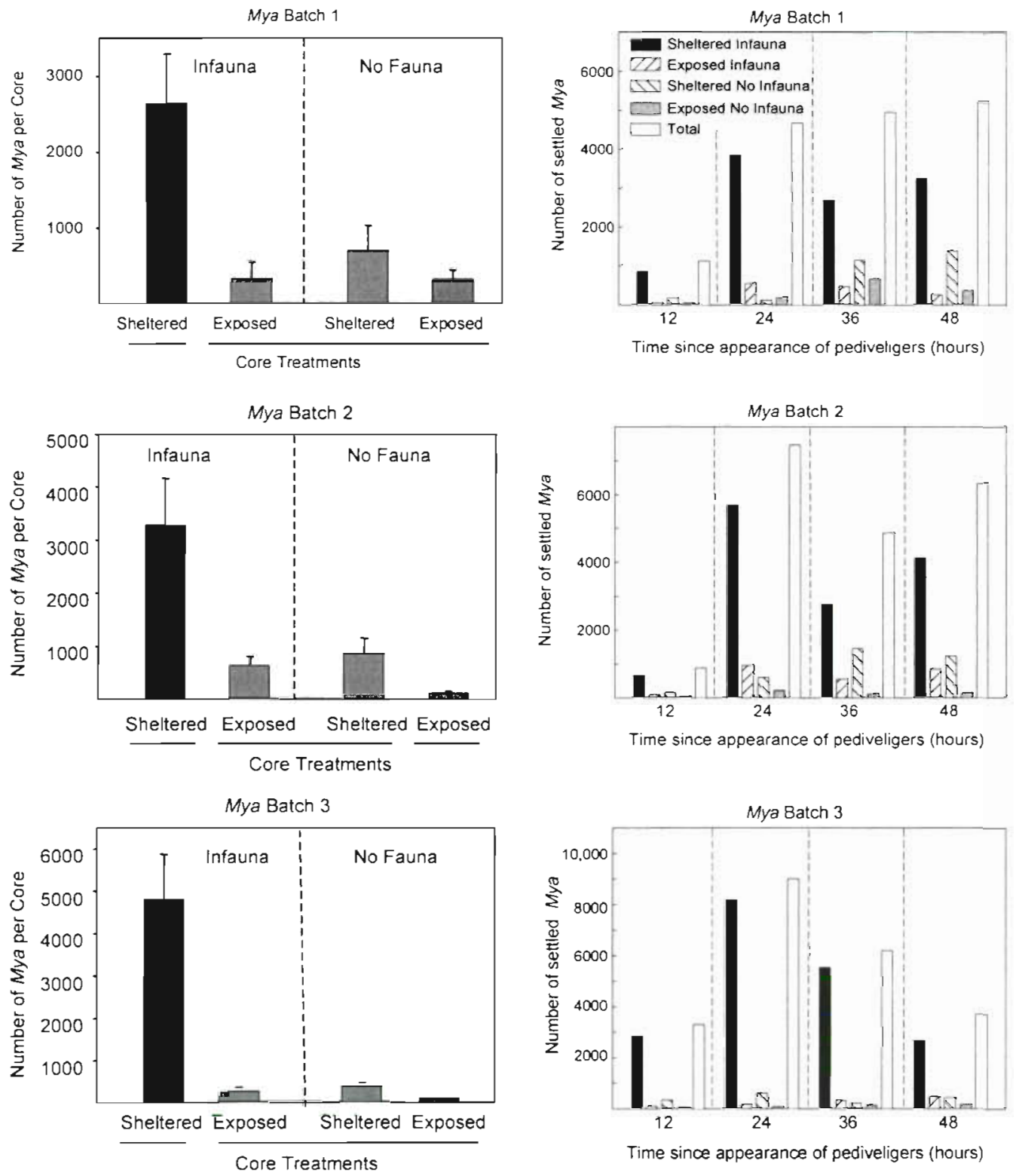

Fig. 3. Results for all flume experiments. Left panels denote $\bar{X} \pm 1$ SE for each treatment across the 4 flume runs within each experiment; lines beneath each plot connect treatments that were not significantly different. Right panels show individual values for each treatment within each run over the course of each experiment. Time since appearance of pediveligers refers to time since $\sim 5 \%$ of the culture had developed as far as the pediveliger stage
Previous flume experiments on larval settlement have deliberately used sediments that have been altered in order to test explicit hypotheses on the importance of grain size, organic content and other key variables. The use of azoic sediments in settlement studies has been criticized (Smith \& Brumsickle 1989) because they are 'unnatural'. Some studies utilized sediments that were azoic and homogenized (Butman et al. 1988, Grassle \& Butman 1989, Butman \& Grassle 1992, Grassle et al. 1992a,b, Snelgrove et al., 1993, 1998), others used sediments that were azoic but with specific chemical attributes (Woodin et al. 1993) and some used sediments with a very simplified fauna (André \& Rosenberg 1991). These flume experiments suggest that near-bed flow (Snelgrove et al. 1993), active habitat selection for sedimentary characteristics such as high organic content (e.g. Butman et al. 1988, Butman \& Grassle 1992, Grassle et al. 1992a,b), coarse grain size/low organic content (Snelgrove et al. 1998) or geochemical cues associated with disturbance (Woodin et al. 1995), and predation by suspension feeders (André et al. 1993) may all contribute to spatial pattern. Although flume experiments with altered sediments have greatly improved our understanding of larval settlement, the next logical application of flume simulations is to use natural communities in manipulations to bridge the gap with field experiments. 

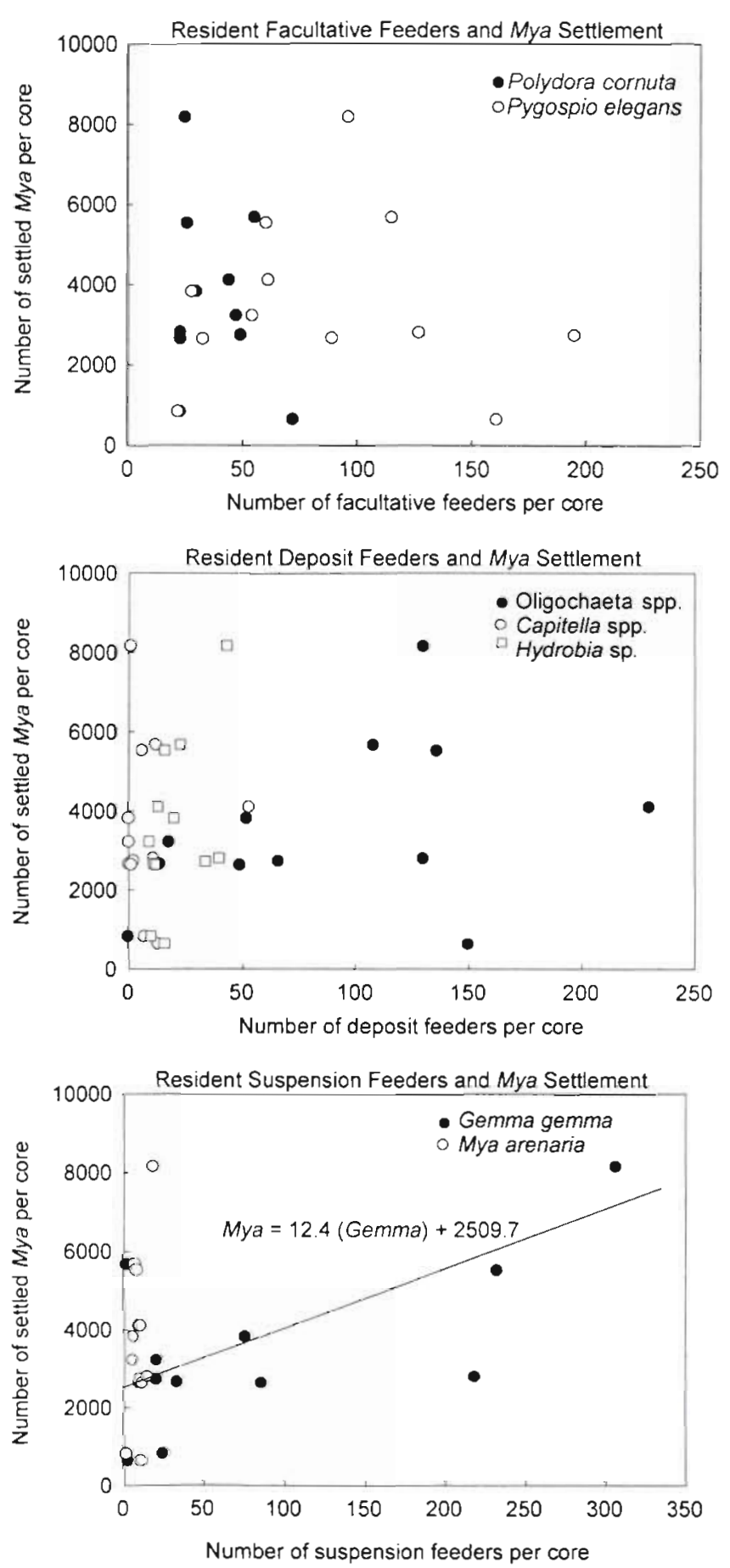

Fig. 4. Plots of relationships between settled Mya arenaria and dominant resident infaunal taxa in all Sheltered Infauna cores used in flume experiments. Core diameter was $4.36 \mathrm{~cm}$

Resident infauna can impact settling larvae via many different mechanisms. Larvae could actively respond to or avoid certain species or associated compounds (e.g. Woodin et al. 1993), fall prey to resident fauna (e.g. Woodin 1976) or fail to compete effectively with other species (e.g. Whitlatch 1980). Structures that extend above the bottom also disturb boundary-layer flow (Eckman 1985, Ertman \& Jumars 1988), as can currents generated by suspension feeders (Monismith et al. 1990); these disturbances could influence settlement patterns of larvae that are delivered to the bed as passive particles (Armonies \& Hellwig-Armonies 1992 Butman \& Grassle 1992, Snelgrove et al. 1993).

Despite similarities in sediment composition (Emerson \& Grant 1991) the fine-scale surface structure and faunas at the Sheltered and Exposed Sites are remarkably different and present interesting questions regarding larval settlement. As is the case with the other dominant taxa at Eastern Passage, Mya arenaria occur at both sites but are more abundant at the Sheltered Site during the summer months when we sampled (Fig. 2). Differences in larval settlement in response to sediment structure or species present could contribute to density differences. The high densities of interface feeders such as Polydora cornuta and Pygospio elegans probably contribute to the concentration of fine material at the sediment-water interface and the distinctly different appearance of the sediment. An additional factor that may contribute to differences in this 'fluff layer' is a sticky microbial film associated with sediment grains at the Sheltered Site that is lacking at the Exposed Site, likely relating to hydrodynamic activity and abrasion (Grant \& Emerson 1994). Alternatively, the species that contribute to these habitat differences could impact $M$. arenaria settlement.

Given that Mya arenaria is more abundant at the Sheltered Site than the Exposed Site during summer, higher settlement should be expected in Sheltered Site cores in flume simulations if habitat selection contributes to field distributions. Indeed, larvae settled in significantly higher numbers in Sheltered Site cores than in corresponding Exposed Site cores, suggesting that settling $M$. arenaria are attracted to some sediment attribute that is only partly destroyed by defaunation/freezing. Although Sheltered No Fauna cores had significantly higher settlement than Exposed No Fauna cores, numbers were far less than in Sheltered Infauna cores. Explanations for this result include active choice by settling larvae for some aspect of the sediment that was greatly reduced by freezing or by removal of adults, differences in sediment biofilming ('stickiness') and larval retention, differences in sediment roughness elements, and thus in passive larval flux to the bed, and increased larval flux to the bed via infaunal feeding activity.

Differences in sediment biofilm may have been a factor, given that biofilming is greater in Sheltered Site sediments than Exposed Site sediments (Grant \& Emerson 1994) and sieving and freezing would likely have altered any biofilm present. Interestingly, Ólafs- 
son (1988) observed higher settlement of Mya arenaria in substratum without red algal mat cover compared to natural or defaunated substratum with mats; combined with our results, this finding suggests that any linkage between settling $M$. arenaria and algae/biofilming differs substantially depending on the specific nature of the organic matter associated with the sediment. Roughness is less likely as an explanation for our treatment differences because the No Infauna cores were not obviously different from Infauna cores with respect to this variable. In addition, none of the core surfaces was perfectly flat, and larger-scale topography that was randomly distributed among treatments would likely have masked any roughness effect induced by tubes etc. If differences in settlement are related to increased larval flux via infaunal feeding currents, or active selection (or avoidance) by larvae for the presence of some species, then the densities of that species should be a significant predictor of $M$. arenaria settlement.

Regression analysis to determine which individual taxa were significant predictors of Mya arenaria settlement was significant only for Gemma gemma. G. gemma is a suspension-feeding bivalve that has been observed to enhance Mercenaria mercenaria settlement in still-water experiments (Ahn et al. 1993). The authors concluded that sediment alteration by G. gemma resulted in active choice by settling $M$. mercenaria in response to multiple cues including sediment geochemistry, roughness, and biodeposits. They eliminated entrapment related to stickiness because individuals were crawling freely. In the present study, if G. gemma did modify sediment in a way that made it more attractive to $M$. arenaria larvae, then freezing destroyed much of whatever made the sediment attractive. G. gemma may help maintain an attractive biofilm layer on sediments (that would be reduced by freezing), either by reducing bioturbation by other species or perhaps by enhancing nutrient flux within the sediment (Weinberg \& Whitlatch 1983 provide an example of a polychaete enhancing nutrient flux and thereby enhancing G. gemma growth). Species-specific compounds (Woodin et al. 1993) that may largely break down in freezing also cannot be dismissed. Given the small size of G. gemma siphons, it is unlikely that their feeding currents increased larval flux to the bed. In any case, the weakness of the relationship indicates that whatever the effect of $G$. gemma, it is probably indirect or possibly even spurious. Interestingly, the finding of enhanced Mya arenaria settlement in the presence of G. gemma is in direct contradiction to previous predictions (Sanders et al. 1962, Emerson \& Grant 1991), based in the former case on an observed inverse relationship between $G$. gemma and $M$. arenaria abundance in the field. Clearly a more complex explanation is needed to clarify these field distributions.
Competency tests indicated highest settlement approximately $24 \mathrm{~h}$ after (presumably competent) pediveligers were observed in the culture. It is interesting, though perhaps coincidental, that settlement in flume experiments tended to peak around this time. Although competency tests offer a crude measure of whether larvae are competent, the degree of variability between replicates and batches punctuates the need for a more definitive and repeatable means of evaluating competency. The absence of high levels of spontaneous settlement in cultures in the later runs of flume experiments suggests that competency in individuals probably lasts for several days but additional data to explicitly test this question are sorely needed. The significant Run effect resulted from changes in total settlement depending on relative age of larvae used in experiments. Given that the degree of selectivity appeared to be highest in Run 2 of all 3 experiments (Fig. 3), and that it tended to be lowest by the final run, it is unlikely that the first 2 sets of experiments were run prematurely. A more likely scenario is that larvae were reaching a point where swimming capacity was reduced by increasing larval size (see Jonsson et al. 1991) with age, and passive deposition became increasingly important in the later flume runs.

An obvious conclusion that might be drawn from this study is that differences in larval settlement between sites could contribute to higher Mya arenaria adult densities at the Sheltered Site. Nonetheless, a more complicated explanation must be invoked. From high frequency sampling throughout the summer months, Emerson \& Grant (1991) documented a complete absence of $M$. arenaria spat at the Sheltered Site and extremely high abundances of spat at the Exposed Site. It is quite possible that differences in larval supply to the 2 sites during their study period contributed to the absence of spat at the Sheltered Site; Günther (1992) noted differences in $M$. arenaria settlement over scales of 100 s of metres in the Wadden Sea. Another possibility is higher densities of predators at the Sheltered Site may quickly remove settled $M$. arenaria, and successful recruitment to the Sheltered Site may be accomplished by post-settlement transport of larger and less vulnerable individuals. In several instances in our flume experiments, guts of spionid polychaetes were full of $M$. arenaria larvae, a finding that is consistent with previous studies that have documented spionid predation on bivalve larvae (Breese \& Phibbs 1972, Daro \& Polk 1973). Predation has been invoked to explain $M$. arenaria patterns elsewhere as well (Möller \& Rosenberg 1983).

Given that the absence of spat at the Sheltered Site was observed during a different year than the present study, and the strong selective behaviour exhibited by Mya arenaria for Sheltered Site cores in the flume 
experiments, the most parsimonious explanation for these findings is that habitat selection can play a role in determining $M$. arenaria pattern but it is not the sole determinant. In some years, supply differences may pre-empt the opportunity to select, and in these years recruitment is either limited or accomplished by postsettlement immigration (Emerson \& Grant 1991, Roegner et al. 1995). Thus, $M$. arenaria pattern at Eastern Passage is likely determined by a combination of preand post-settlement processes.

Acknowledgements. We are grateful to A. Mallet for advice on conditioning and spawning clams, to D. Krailo for kindly providing large volumes of phytoplankton, and to K. Bryan, M. D. DuRand, and C. D. Snelgrove for assistance in the field $\mathrm{S}$. Fraser assisted in sorting samples and R. Petrecca and K. Gilkinson provided taxonomic advice. B. Schofield provided valuable suggestions and advice on flume modifications, and P. MacPherson assisted in flume logistics. The assistance of persornel associated with Dalhousie's Aquatron facility, particularly E. Officia and S. Fowler, is greatly appreciated. Discussions with J. P. Grassle and C. W. Emerson helped clarify our thinking. Comments from L. Mullineaux and 2 anonymous reviewers substantially improved the manuscript. P.V.R.S. was supported by a Dalhousie Killam Postdoctoral Fellowship and an NSERC Industrial Research Chair in Fisheries Conservation

\section{LITERATURE CITED}

Ahn IY, Malouf R, Lopez G (1993) Enhanced larval settlement of the hard clam Mercenaria mercenaria by the gem clam Gemma gemma. Mar Ecol Prog Ser 99:51-59

Ambrose WG Jr (1984) Influence of residents on the development of a marine soft-bottom community. $J$ Mar Res 42:633-654

André C, Rosenberg R (1991) Adult-larval interactions in the suspension-feeding bivalves Cerastoderma edule and Mya arenaria. Mar Ecol Prog Ser 71:227-234

André C, Jonsson PR, Lindegarth M. (1993) Predation on settling bivalve larvae by benthic suspension feeders: the role of hydrodynamics and larval behaviour. Mar Ecol Prog Ser 97:183-192

Armonies W, Hellwig-Armonies M (1992) Passive settlement of Macoma balthica spat on tidal flats of the Wadden Sea and subsequent migration of juveniles. Neth $\mathrm{J}$ Sea Res 29:371-378

Bell SS, Coull BC (1980) Experimental evidence for a model of juvenile macrofauna-meiofauna interactions. In: Tenore KR, Coull, BC (eds) Marine benthic dynamics. University of South Carolina Press, Columbia, p 179-192

Breese WP, Phibbs FD (1972) Ingestion of bivalve molluscan larvae by the polychaete annelid Polydora ligni. Veliger $14: 274$

Butman CA (1987) Larval settlement of soft-sediment invertebrates: the spatial scales of pattern explained by active habitat selection and the emerging role of hydrodynamical processes. Oceanogr Mar Biol Annu Rev 25:113-165

Butman CA, Grassle JP (1992) Active habitat selection by Capitella sp. I larvae. I. Two-choice experiments in still water and flume flows. J Mar Res 50:669-715

Butman CA, Grassle JP, Webb CM (1.988) Substrate choices made by marine larvae settling in still water and in a flume flow. Nature 333:771-773

Cameron RA, Rumrill SS (1982) Larval abundance and recruitment of the sand dollar Dendraster excentricus in Monterey Bay, California, USA. Mar Biol 71:197-202

Daro MH, Polk P (1973) The autoecology of Polydora ciliata along the Belgian coast. Neth J Sea Res 6:130-140

Eckman JE (1983) Hydrodynamic processes affecting benthic recruitment. Limnol Oceanogr 28:241-257

Eckman JE (1985) Flow disruption by an animal-tube mimic affects sediment bacterial colonization. J Mar Res 43: $419-435$

Emerson CW (1991) The simultaneous measurement of bedload sediment transport and infaunal transport on intertidal sandflats. Estuaries 14:361-371

Emerson CW, Grant J (1991) The control of soft-shell clam (Mya arenaria) recruitment on intertidal sandflats by bedload sediment transport. Limnol Oceanogr 36:1288-1300

Ertman SC, Jumars PA (1988) Effects of bivalve siphonal currents on the settlement of inert particles and larvae. J Mar Res 46:797-813

Gallagher ED, Jumars PA, Trueblood DD (1983) Facilitation of soft-bottom benthic succession by tube builders. Ecology 64:1200-1216

Gosner KL (1978) A field guide to the Atlantic seashore. Houghton-Mifflin, Boston

Grant J, Emerson C (1994) Resuspension and stabilization of sediments with microbial biofilms: implications for benthic-pelagic coupling. In: Krumbein WE, Paterson DM, Stal LJ (eds) Biostabilization of sediments. Bibliotheks und Informationssystem der Universität Oldenburg, Oldenburg, p 121-134

Grassle JP, Butman CA (1989) Active habitat selection by larvae of the polychaetes, Capitella spp. I and II, in a laboratory flume. In: Ryland JS, Tyler PA (eds) Reproduction, genetics and distributions of marine organisms. Proc 23rd Eur Mar Biol Symp. Olsen \& Olsen, Fredensborg, p 107-114

Grassle JP, Snelgrove PVR, Butman CA (1992a) Larval habitat choice in still water and flume flows by the opportunistic bivalve Mulinia lateralis. Neth J Sea. Res 30:33-44

Grassle JP, Butman CA, Mills SW (1992b) Active habitat selection by Capitella sp. I larvae. II. Multiple-choice experiments in still water and flume flows. J Mar Res 50:717-743

Günther CP (1991) Settlement of Macoma balthica on an intertidal sandflat in the Wadden. Sea. Mar Ecol Prog Ser $76: 73-79$

Günther CP (1992) Settlement and recruitment of Mya arenaria L. in the Wadden Sea. J Exp Mar Biol Ecol 159:203-215

Hall SJ, Basford DJ, Robertson MR, Raffaelli DG, Tuck I (1991) Patterns of recolonisation and the importance of pit-digging by the crab Cancer pagurus in a subtidal sand habitat. Mar Ecol Prog Ser 72:93-102

Huettel $M$, Gust $G$ (1992) Impact of bioroughness on interfacial solute exchange in permeable sediments. Mar EcoI Prog Ser 89:253-267

Jonsson PR, André C, Lindegarth M (1991) Swimming behaviour of marine bivalve larvae in a flume boundary-layer flow: evidence for near-bottom confinement. Mar Ecol Prog Ser 79:67-76

Jumars PA, Nowell ARM (1984) Fluid and sediment dynamic effects on marine benthic community structure. Am Zool $24: 45-55$

Luckenbach MW (1984) Settlement and eariy post-settlement survival in the recruitment of Mulinia lateralis (Bivalvia). Mar Ecol Prog Ser 17:245-250 
Luckenbach MW (1986) Sediment stability around animal tubes: the roles of hydrodynamic processes and biotic activity. Limnol Oceanogr 31:779-787

Miller DC, Bock MJ, Turner EJ (1992) Deposit and suspension feeding in oscillatory flows and sediment fluxes. J Mar Res 50:489-520

Möller P, Rosenberg R (1983) Recruitment, abundance and production of Mya arenaria and Cardium edule in marine shallow waters, western Sweden. Ophelia 22:33-55

Monismith SG, Koseff JR, Thompson JK, O'Riordan CA, Nepf HM (1990) A study of model bivalve siphonal currents. Limnol Oceanogr 35:680-696

Muus K (1973) Settling, growth and mortality of young bivalves in the Øresund. Ophelia 12:79-116

Nowell ARM, Jumars PA (1984) Flow environments of aquatic benthos. Annu Rev Ecol Syst 15:303-328

Nowell ARM, Jumars PA (1987) Flumes: theoretical and experimental considerations for simulation of benthic environments. Oceanogr Mar Biol Annu Rev 25:91-112

Olafsson EB (1988) Inhibition of larval settlement to a soft bottom benthic community by drifting algal mats: an experimental test. Mar Biol 97:571-574

Olafsson EB, Peterson CH, Ambrose WG Jr (1994) Does recruitment limitation structure populations and communities of macro-invertebrates in marine soft sediments. the relative significance of pre- and post-settlement processes. Oceanogr Mar Biol Annu Rev 32:65-109

Peterson $\mathrm{CH}$ (1979) Predation, competitive exclusion, and diversity in the soft-sediment benthic communities of estuaries and lagoons. In: Livingston RJ (ed) Ecological processes in coastal and marine systems. Plenum, New York, p 233-264

Peterson CH (1982) The importance of predation and intraand interspecific competition in the population biology of two infaunal suspension-feeding bivalves, Protothaca staminea and Chione undatella. Ecol Monogr 52:437-475

Roegner $\mathrm{C}$, Andre $\mathrm{C}$, Lindegarth $\mathrm{M}$, Eckman JE, Grant J (1995) Transport of recently settled soft-shell clams (Mya arenaria $\mathrm{L}$.) in laboratory flume flow. J Exp Mar Biol Ecol $187: 13-26$

Sanders HL, Goudsmit EM, Mills EL, Hampson GE (1962) A study of the intertidal fauna of Barnstable Harbor, Massachusetts. Limnol Oceanogr 7:63-79

Smith CR, Brumsickle SJ (1989) The effects of patch size and substrate isolation on colonization modes and rates in an intertidal sediment. Limnol Oceanogr 34:1263-1277

Snelgrove PVR (1994) Hydrodynamic enhancement of invertebrate larval settlement in microdepositional environ-

Editorial responsibility: Joseph Pawlik (Contributing Editor), Wilmington, North Carolina, USA ments: colonization tray experiments in a muddy habitat. J Exp Mar Biol Ecol 176:149-166

Snelgrove PVR, Butman CA (1994) Animal-sediment relationships revisited: cause versus effect. Oceanogr Mar Biol Annu Rev 32:111-177

Snelgrove PVR, Butman CA, Grassle JP (1993) Hydrodynamic enhancement of larval settlement in the bivalve Mulinia lateralis (Say) and the polychaete Capitella sp. I in microdepositional environments. J Exp Mar Biol Ecol 168: $71-109$

Snelgrove PVR, Grassle JP, Butman CA (1998) Sediment choice by settling larvae of the bivalve, Spisula solidissima (Dillwyn), in flow and still water. J Exp Mar Biol Ecol 231. $171-190$

Tamaki A (1985) Inhibition of larval recruitment of Armandia sp. (Polychaeta: Opheliidae) by established adults of Pseudopolydora paucibranchiata (Okuda) (Polychaeta: Spionidae) on an intertidal sand flat. J Exp Mar Biol Ecol $87: 67-82$

Turner SJ, Grant J, Pridmore RD, Hewitt JE, Wilkinson MR, Hume TM, Morrisey DJ (1997) Bedload and water-column transport and colonization processes by post-settlement benthic macrofauna: does infaunal density matter? J Exp Mar Biol Ecol 216:51-75

Watzin $M$ (1986) Larval settlement into marine soft-sediment systems: interactions with the meiofauna. J Exp Mar Biol Ecol 98:65-113

Weinberg JR, Whitlatch RB (1983) Enhanced growth of a filter-feeding bivalve by a deposit-teeding polychaete by means of nutrient regeneration. J Mar Res 41:557-569

Whitlatch RB (1980) Patterns of resource utilization and coexistence in marine intertidal deposit-feeding communities. J Mar Res 38:743-765

Wilson WH (1991) Competition and predation in marine softsediment communities. Annu Rev Ecol Syst 21:221-241

Woodin SA (1976) Adult-Larval interactions in dense infaunal assemblages: patterns of abundance. J Mar Res 34: $25-41$

Woodin SA (1985) Effects of defecation by arenicolid polychaete adults on spionid polychaete juveniles in field experiments: selective settlement or differential mortality. J Exp Mar Biol Ecol 87:119-132

Woodin SA, Marinelli RL, Lincoln DE (1993) Allelochemical inhibition of recruitment in a sedimentary assemblage. J Chem Ecol 19:517-530

Woodin SA, Lindsay SM, Wethey DS (1995) Process-specific recruitment cues in marine sedimentary systems. Biol Bull $189: 49-58$

Submitted: May 21, 1998; Accepted: January 12, 1999 Proofs received from author(s): May 11, 1999 